\title{
A Complication of Female Circumcision: Vaginal Stenosis and Total Incontinence Due to Urethral Intercourse
}

\section{Bir Kadın Sünneti Komplikasyonu: Vajinal Stenoz ve Üretral Ilişki Sonrası Total Inkontinans}

\author{
Deniz Arslan1, Ozan Bozkurt2, Özer Birge3, Ömer Demir2, Adil Esen2 \\ 1 Turkey Training and Research Hospital, Clinic of Urology, Nyala, Sudan \\ 2Dokuz Eylül University Faculty of Medicine, Department of Urology, Izmir, Turkey \\ 3Turkey Training and Research Hospital, Clinic of Obstetrics and Gynecology, Nyala, Sudan
}

\begin{abstract}
Female genital mutilation (FGM) is a horrible procedure which may have detrimental physical and pyschological effects on women and mostly performed in the Middle East and African regions. FGM has four different types described in various regions. Total urinary incontinence due to type 3 FGM is described in a 21-year-old female in the present article.
\end{abstract}

Key Words

Female circumcision, incontinence, urethral intercourse

\section{ÖZET}

Kadın sünneti bugün için daha çok Ortadoğu ve Afrika gibi bölgelerde uygulanan ve kadınlar açısından ciddi derecede fiziksel ve psikolojik sonuçları olabilen kötü bir uygulamadır. Kadın sünnetinin farkıı bölgelerde uygulanan tanımlanmış 4 farklı tipi mevcuttur. Bu olguda 21 yaşında bir kadın hastada tip 3 kadın sünneti sonrası gelişen total inkontinans olgusu sunulmaktadır.

Anahtar Kelimeler

Kadın sünneti, inkontinans, üretral ilişki

\section{Introduction}

Female genital mutilation (FGM) is defined by the World Health Organization (WHO) as all procedures that involve partial or total removal of the female external genitalia for nontherapeutic reasons and classified as type 1- total or partial clitorectomy; type 2- excision of the clitoris with partial or total excision of the labia minora; type 3- excision of part or all of the external genitalia and stitching/ narrowing of the vaginal opening (infibulation) and type 4 which includes pricking, piercing or incising of the clitoris and/or labia or cauterization without any excisional procedure (1). FGM is common in the Middle East and African regions and usually performed at age between 5 and 12 years and sometimes in adulthood (2). This procedure is performed with a knife, razor blade or sharp glass with or without local anesthesia by grappling girls by force.

The worst one, infibulation, is performed in Djibouti, Eritrea, Ethiopia, Somalia and Sudan (3). Feet of the girls are tied to each other for supporting the adhesion of wound edges after suturization (4).
Complications vary according to the hygiene status, instruments, experience of the operator and type of circumcision (1). Problems such as inability to have intercourse, infertility, dysmenorrhoea, endometriosis and voiding dysfunction are encountered in girls undergoing type 3 FGM (5).

\section{Case Report}

A 21-year-old female, who was married for 3 years and had no child, was admitted to our clinic with urinary incontinence. She was complaining of pain and discomfort, bleeding and much more urinary incontinence during sexual intercourse. She described a few unsuccessful intercourse experiences since married and her husband married another woman because she could not try more because of great pain during sexual intercourse. She was describing extreme groin and flank pain during menstrual period. She was describing a small amount of bleeding during menstrual period.

Physical examination revealed that she had undergone type 3 FGM (Figure 1 and 2). Vaginal introitus was totally closed. A small orifice

\section{Correspondence}

Ozan Bozkurt MD, Dokuz Eylül University Faculty of Medicine, Department of Urology, İzmir, Turkey

Phone: +90 2324123450 E-mail: drozanbozkurt@gmail.com Received: 15.10.2014 Accepted: 21.01.2015 


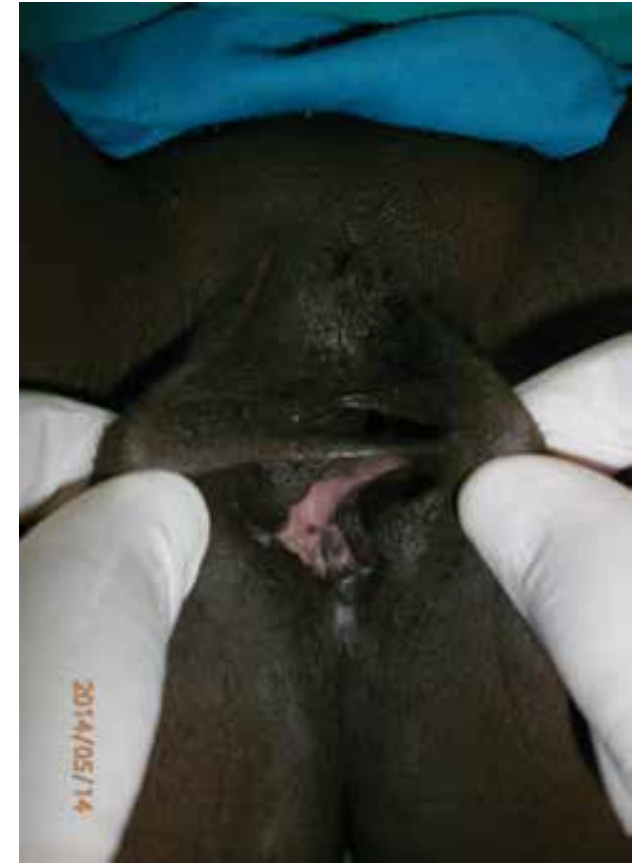

Figure 1. Vaginal stenosis due to type 3 female circumcision

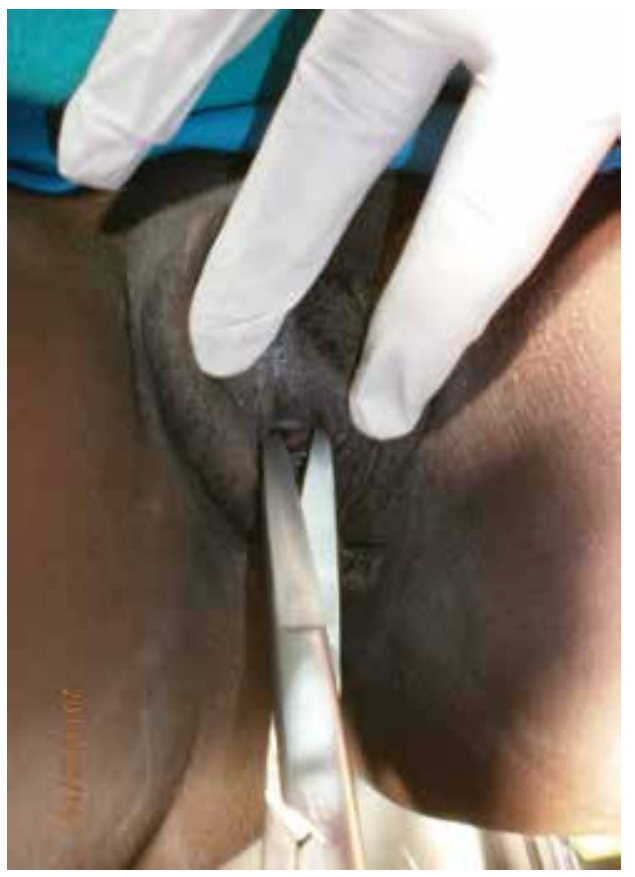

Figure 2. Enlarged urethral orifice due to urethral intercourse was seen in the vaginal introitus. Ten Fr urinary catheter could not be placed. It was seen that the urethral orifice was so enlarged that insertion of two fingers was possible. She underwent vaginoplasty and megaurethra plication for reconstruction.

\section{Discussion}

Methods of female circumcision are defined as cutting of female genital organs (Female Genital Cutting), mutilation of genitalia-FGM or bruising female genitalia intentionally for non-therapeutic reasons (1). The number of women undergoing this procedure is declining with the help of fighting against this procedure both in Europe and also in the countries where this procedure is performed, however, it is still common in Middle East and Africa (3).

This procedure has several early and late complications. Early complications include shock, hemorrhage, infections and psychological problems $(6,7)$. Late health-related problems can be ranged as chronic pain, infections, keloid formation, primary infertility, birth-related complications, possible harmful effects for the infant, and psychological problems $(8,9)$. Complication rates vary according to FGM type and fibrosis, keloid formation and adhesions are more frequent with type 3 FGM (10). The vagina was totally closed also in our case due to the fibrosis and adhesions caused by type 3 FGM. She had amenorrhea and was describing serious pain during menstrual period. No pathologic finding was detected in our case on abdominal USG examination despite some previous reports demonstrating hematocolpos or pelvic mass due to closed vaginal orifice (11).

Infertility is one of the complications of FGM. This is usually a consequence of tubal obstruction after early vaginitis, oophoritis and tubal adhesions following the procedure (12). Inability to have sexual intercourse due to vaginal occlusion was the main factor causing infertility in our case.

Data regarding urethral intercourse in the current literature is scarce and only 26 cases have been presented. Urethral coitus has been reported in only one case due to stenotic vagina after operation for ambiguous genitalia (13). We did not face another urethral coitus case due to vaginal stenosis as a consequence of FGM in the existing literature. Women mostly complain of urinary incontinence and/or dyspareunia after urethral intercourse (14). Our case had also extreme pain during intercourse with concomitant urinary incontinence during and after sexual intercourse. Thereafter, total incontinence developed.

In conclusion; although accepted as an assault and infringement against women's rights, FGM is still common in several countries. It is once more demonstrated with this report that this procedure completely changes vaginal anatomy and has serious complications. Therefore, educational programs and practices are required where these procedures are common.

Concept: Deniz Arslan, Ozan Bozkurt

Design: Deniz Arslan, Ozan Bozkurt, Özer Birge

Data Collection or Processing: Deniz Arslan, Özer Birge, Adil Esen

Analysis or Interpretation: Ömer Demir, Adil Esen

Literature Search: Deniz Arslan, Ozan Bozkurt, Ömer Demir

Writing: Deniz Arslan, Ozan Bozkurt

Peer-review: Externally peer-reviewed.

Conflict of Interest: No conflict of interest was declared by the authors.

Financial Disclosure: The authors declared that this study has received no financial support.

\section{References}

1. World Health Organization, Department of Reproductive Health and Research. Eliminating female genital mutilation: an interagency statement. Geneva: WHO; 2008.

2. Shah G, Susan L, Furcroy J. Female circumcision: history, medical and psychological complications, and initiatives to eradicate this practice. Can J Urol 2009;16:4576-4579. 
3. Yoder PS, Khan S; USAID. Numbers of women circumcised in Africa: the production of a total. DHS Working Paper 39. Claverton MD: Macro International; 2008.

4. Perron L, Senikas V, Burnett M, Davis V; Society of Obstetricians and Gynaecologists of Canada. Female genital cutting. J Obstet Gynaecol Can 2013;35:1028-1045.

5. MacLeod TL. Female genital mutilation. J SOGC 1995;17:333-342.

6. Nour NM. Female genital cutting: clinical and cultural guidelines. Obstet Gynecol Surv 2004;59:272-279.

7. Almroth $L$, Bedri $H$, El Musharaf $S$, Satti $A$, Idris $T$, Hashim $M$, Suliman GI, Bergström S:Urogenital Complications among Girls with Genital Mutilation: A Hospital-Based Study in Khartoum. African Journal of Reproductive Health 2005.

8. Behrendt A, Moritz S. Posttraumatic Stress Disorder and Memory Problems After Female Genital Mutilation. Am J Psychiatry 2005;162:1000-1002.

9. Alsibiani SA, Rouzi AA. Sexual function in women with female genital mutilation. Fertil Steril 2010;93:722-724.
10. Banks E, Meirik O, Farley T, Akande O, Bathija H, Ali M; WHO Study Group on Female Genital Mutilation and Obstetric Outcome. Female genital mutilation and obstetric outcome: WHO collaborative prospective study in six African countries. Lancet 2006;367:1835-1841.

11. Kaplan $A$, Hechavarria $S$, Martin M, Bonhoure I. Health consequences of female genital mutilation/cutting in the Gambia, evidence into action. Reprod Health 2011;8:26.

12. Drakonaki EE, Tritou I, Pitsoulis G, Psaras K, Sfakianaki E. Hematocolpometra due to an imperforate hymen presenting with back pain: sonographic diagnosis. J Ultrasound Med 2010;29:321-322.

13. Yount KM , Carrera JS. Female genital cutting and reproductive experience in Minya, Egypt. Med Anthropol 0 2006;20:182-211.

14. Sakinci M, Kokcu A, Malatyalioglu E. Satisfactory urethral coitus in a patient with vaginal stenosis: case report. Int Urogynecol J 2012;23:237239.

15. Ryckman J, Black A, Fleming N. Adolescent Urethral Coitus: 2 Cases and Review of the Literature. J Pediatr Adolesc Gynecol 2014;27:e9-12. 